\title{
Smittevernloven og tvang
}

\author{
Få leger har hatt erfaring med tvangstiltak etter smittevernloven. Vi vet fra flere henvendelser at det er \\ en del usikkerhet om fremgangsmåten når tvangstiltak vurderes. I denne artikkelen gjennomgår vi vilkårene \\ for tvangsvedtak etter smittevernloven samt den praktiske fremgangsmåten dersom tvangstiltak kan være \\ aktuelt.
}

Tore Wælgaard Steen

tore.steen@hel.oslo.kommune.no

Trude Margrete Arnesen

> Se lederartikkel på side 1342

Smittevernloven trådte i kraft 1.1. 1995 (1-4). Den bygger i all vesentlighet på tillit og frivillighet. I enkelte situasjoner der frivillige løsninger ikke fører frem, åpner likevel loven for bruk av tvang dersom dette er nødvendig for å beskytte andre mot smitte.

Loven har to «tvangsparagrafer», §5-2 og § 5-3. § 5-2 omhandler tvungen legeundersøkelse og innleggelse til undersøkelse og kortvarig isolering. § 5-3 omhandler tvungen isolering i sykehus. Vedtak etter disse paragrafene skal gjøres av en sentral nemnd - smittevernnemnda - med unntak av hastevedtak etter $\S 5-2$. Smittevernnemnda har behandlet forholdsvis få saker, gjennomsnittlig under én sak i året (5), og det har trolig vært truffet svært få hastevedtak.

\section{$\S$ 5.2. Tvungen legeundersøkelse}

Det kan gjøres vedtak om at en smittet person skal innlegges for undersøkelse og eventuelt kortvarig isolering $i$ inntil sju dager (undersøkelse kan også skje poliklinisk eller på annet egnet sted). Vilkårene, som alle må være oppfylt, er:

- Lege eller kommunelege (smittevernlege) skal ha anmodet en mistenkt smittet om å la seg undersøke

- Frivillighet er forsøkt, men har ikke ført frem, eller frivillige tiltak anses som nytteløse

- Vedkommende må ha kliniske symptomer eller tegn på allmennfarlig smittsom sykdom eller legen må ha sikker kunnskap om at vedkommende har vært utsatt for smitte

- Undersøkelse (diagnostikk) og eventuell isolering er nødvendig for å motvirke overføring til andre

- Undersøkelse kan skje uten fare

Dersom det allerede er på det rene at vedkommende har en allmennfarlig smittsom sykdom, dvs. det foreligger en sikker diagnose, kan § 5-2 ifølge Krogsrud ikke benyttes (6).

\section{§ 5-3. Tvungen isolering i sykehus}

Det kan gjøres vedtak om at en smittet person skal legges inn i sykehus for isolering i inntil tre uker. Ved nytt vedtak kan isoleringstiden forlenges med opptil seks uker om gangen i inntil ett år. Vilkårene er:

- Den smittede er blitt anmodet om å la seg isolere, men frivillighet har ikke ført frem, jf. ovenstående

- Smittefaren må være brakt på det rene, dvs. allmennfarlig smittsom sykdom må være påvist

- Det er overveiende sannsynlig at andre vil bli smittet dersom isolering ikke iverksettes

- Etter en helhetsvurdering er tvangsisolering den klart mest forsvarlige løsningen ut fra faren for smitteoverføring og den belastningen som tvangsinngrepet kan medføre

I forbindelse med forlenget tvangsisolering kan det også vedtas tvungen medikamentell behandling. Vilkårene er:

- Behandlingen kan redusere isoleringstiden vesentlig og gjøre vedkommende smittefri

- Behandlingen må være uten fare eller større ubehag

\section{Når er tvang aktuelt?}

Lovteksten sier at tvangstiltak kan anvendes ved allmennfarlige smittsomme sykdommer, uten at det skilles mellom disse. Under behandlingen i Stortinget bemerket sosialkomiteen at tvangstiltak skal være «en siste utvei i enkelttilfeller av særlig alvorlig natur, der hensynet til smittevernet gjør det tvingende nødvendig» (4). Komiteen uttalte også at «før tvangsisoleringsvedtak blir gjort, må pasienten også få tilbud om andre tilfredsstillende behandlings- og omsorgstilbud selv om slike tilbud rent økonomisk skulle koste samfunnet mer enn isolering $\mathrm{i}$ institusjon».

I lovforarbeidene (1-4) er særlig hiv/aids og tvangstiltakene diskutert. Dette må ses i lys av at de hivpositives interesseorganisa- sjoner den gang fryktet at en ny lov ville åpne for tvangstesting eller tvangsinternering i stor skala. Det var nødvendig for myndighetene å gjøre det klart at så ikke ville skje.

I praksis har tvangshjemlene $\mathrm{i}$ all hovedsak vært brukt ved påvist eller mistenkt smitteførende tuberkulose der aktuelle person nektet undersøkelse eller behandling eller forsvant fra behandling (5). Vi kjenner bare til ett tilfelle der de har vært brukt ved hiv/aids (5). I lovforarbeidene er ellers

\section{«Tvangstiltak kan anvendes ved allmenn- farlige smittsomme sykdommer»}

mistanke om hepatitt B og mistanke om difteri angitt som eksempler på tilstander der tvungen legeundersøkelse kan være aktuelt dersom en person nekter å la seg undersøke (1).

\section{Begjæring om vedtak etter § 5-2 eller § 5-3}

Etter $\S 5-5$ skal kommunelegen utarbeide begjæring om tvangstiltak. Det må dokumenteres at vilkårene for bruk av tvang er til stede. Det må redegjøres for sykehistorie, hvilke tiltak som er forsøkt for å oppnå frivillighet og hvorfor tvang anses å være nødvendig. Begjæringen sendes via Fylkesmannen, som så omgående skal sende den videre til smittevernnemnda. Fylkesmannen kan imidlertid gi veiledning til kommunelegen dersom han finner forslaget mangelfullt, eventuelt komme med innsigelser til nemnda dersom kommunelegen opprettholder forslaget (6). Departementet har bestemt at fylkesnemnda for sosiale saker i Oslo og Akershus skal være smittevernnemnd for hele landet.

Det er ikke noe krav om at kommunen skal benytte fullmektig (advokat), men det er et ønske fra smittevernnemndas side og 
er blitt gjort i de fleste sakene. Gangen har da vært at kommunelegen gir nødvendige medisinske og andre saksopplysninger til fullmektigen, som utarbeider begjæring og kontakter smittevernnemnda for å beramme møte m.m.

\section{Møtet i nemnda}

Nemnda består av en jurist, som er lederen, et fagkyndig medlem, som er lege, og en legmann. Nemnda skal oppnevne fullmektig for den smittede. Den smittede kan selv være til stede hvis han/hun ønsker det. Vanligvis vil fullmektigen legge frem saken fra kommunens side. Begge parter kan føre vitner. Det har vært vanlig at kommunelegen vitner, noen ganger også en spesialist som har behandlet pasienten.

Vedtak skal treffes «umiddelbart», i praksis stort sett samme dag eller dagen etter møtet. Vedtak i nemnda kan ankes til tingretten, men en klage har ikke oppsettende virkning.

\section{Hastevedtak}

Etter $\S 5-8$ kan det treffes hastevedtak etter $\S 5-2$ av kommunelegen sammen med lege utpekt av regionalt helseforetak (etter $\S 7-3$ tredje ledd). Alle regionale helseforetak har utnevnt en slik lege, og Fylkesmannen bør ha oversikt over hvem som er oppnevnt.

Hovedregelen er imidlertid at vedtak etter $\S 5-2$ skal treffes av nemnda, og man bør kontakte lederen av smittevernnemnda på forhånd dersom hastevedtak er aktuelt (6). Det vil også være fornuftig å diskutere saken med Fylkesmannen. Det må begrunnes særskilt hvorfor undersøkelsen ikke kan vente til etter et eventuelt vedtak i smittevernnemnda (7). Dersom kommunelegen og helseforetakslegen er uenige, skal saken avgjøres av Fylkesmannen.

Smittevernnemnda bør underrettes om hastevedtak $(2,6)$. Et hastevedtak er prinsipielt å anse som et vedtak truffet av nemnda og kan ikke overprøves av denne, bare av tingretten.

\section{Effektuering av vedtak}

Når det er truffet tvangsvedtak, kan kommunelegen om nødvendig kontakte politiet for å få oppsporet en smittet person eller få brakt vedkommende til sykehus, jf. § 4-10. Man må da sørge for å gi politiet nødvendige råd om eventuell bruk av beskyttelsesutstyr.

\section{Oppheving og forlengelse av vedtak} I saker der det er gjort et vedtak, bør kommunelegen ha tett kontakt med avdelingen. Etter $§ 5$-3 skal avdelingens overlege oppheve tvangsvedtaket så snart vilkårene for innleggelse ikke lenger er til stede. Dersom det anses å være nødvendig med forlengelse av tvangsisoleringen, må kommunelegen fremme ny begjæring for smittevernnemnda før isoleringstiden går ut.

Noen pasienter med tuberkulose blir raskt smittefri under behandling, bedømt ut fra laboratorieprøver. Faren kan imidlertid være høy for at de får residiv eller utvikler resistens dersom behandlingen avbrytes for tidlig. Dersom risikoen for at pasienten vil avbryte behandlingen ved utskrivning anses som høy, bør kommunelegen overveie å begjære fortsatt isolering, selv om lovverket ikke er helt klart på dette punktet.
Vi takker Petter Wulfsberg, fylkesnemnda for sosiale saker i Oslo og Akershus, for gjennomlesing av manuskriptet.

Tore Wælgaard Steen (f. 1950) er overlege i Helseetaten, Oslo kommune. Forfatter har fylt ut ICMJE-skjemaet og oppgir ingen interessekonflikter.

Trude Margrete Arnesen (f. 1967) er overlege ved Avdeling for infeksjonsovervåking, Nasjonalt folkehelseinstitutt.

Forfatter har fylt ut ICMJE-skjemaet og oppgir ingen interessekonflikter.

Litteratur

1. Norges offentlige utredninger. Lov om vern mot smittsomme sykdommer (smittevernloven). NOU 1990: 2.

2. Prop. 91 L (1992-93). Om lov om vern mot smittsomme sykdommer (smittevernloven).

3. Prop. $28 \mathrm{~L}(1993-94)$. Om lov om vern mot smittsomme sykdommer (smittevernloven).

4. Innst. 37 L (1993-94). Innstilling fra sosialkomitéen om lov om vern mot smittsomme sykdomme (smittevernloven).

5. Steen TW, Arnesen TM. Tvangstiltak etter smittevernloven 1995-2013. Tidsskr Nor Legeforen 2014; 134: 1357-60

6. Krogsrud B. Smittevernloven. Kommentarutgave. Oslo: Juridisk forlag. 1995

7. Smittevernloven. Veileder. IK-8/95. Oslo: Statens helsetilsyn, 1995.

Mottatt 6.1. 2014 og godkjent 18.3. 2014. Redaktør: Kari Tveito.

Podkast på www.tidsskriftet.no 